\title{
Slow+Design as sustainable sensoriality: an innovative approch aimed to explore the new relationships among design, innovation and sustainability
}

\section{Ceppi, Giulio}

Resumen: A partir de la experiencia de Slow Food y su éxito internacional, el autor, junto con Giacomo Mojoli (ex vicepresidente de Slow Food) comienza a cuestionar el transferimento del enfoque slow en la práctica del diseño.

Esto significa discutir si puede y cómo puede el diseño contribuir al campo de los sistemas y dirigir las transformaciones en curso hacia formas sostenibles de vivir y producir. La expresión Sensorialidad Sostenible quiere combinar ambos mundos de sensorialidad y sostenibilidad, dimensiones conceptuales y operacionales del diseño, pero profundamente practicadas en las actividades de los autores como

Cuadernos del Centro de Estudios de Diseño y Comunicación №70

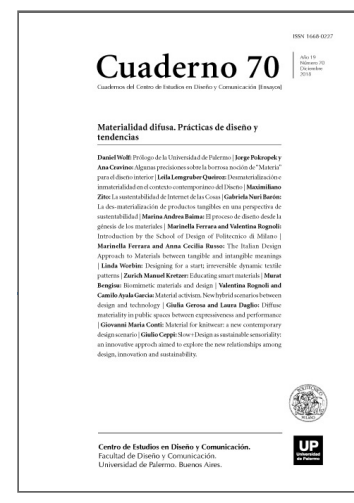

ISSN: 1668-0227

Materialidad difusa.

Prácticas de diseño y

tendencias

Año XIX, Diciembre 2018, Buenos Aires, Argentina | 172 páginas

descargar PDF

ver índice de la publicación

Ver todos los libros de la publicación

compartir en Facebook arquitecto y diseñador, y explicitada en muchas prácticas de enseñanza y en muchos casos de estudio de diseño.

Palabras clave: Sostenibilidad - Sensorialidad - Enfoque slow - Innovación - Diseño de sistemas - Cambios en la práctica.

$\left(^{*}\right)$ Architect designer, PhD, researcher and assistant professor at the Design School of Politecnico di Milano, and member of MADEC at Design Department. His activities are focused on sensorial design, development of new materials and technologies, and on design strategy. He was the coordinator of the Domus Academy Research Center in Milan and senior design consultant at Philips Design. In 1999 he founded Total Tool Milano, a design network with offices in Milan, Buenos Aires and Tokyo, consulting and designing new business ideas for international group. 


\subsection{Taking the slow culture in account}

Our departure point was the Slow Food experience. Slow Food has met with great and growing international success which, contrary to dominant trends, has demonstrated the real possibility of linking food quality research to the safeguarding of typical local products and to the sustainable valorisation of the skills, expertise and organisational models from which such products originate. In so doing it has played an important role on two complementary fronts:

1. firstly, in regenerating such a precious collective good as the biological and cultural diversity of local food production

2. secondly, in proposing and initially setting up new food networks.

However, though the specific scope of Slow Food lies in these new food networks, its experienceis of more general value and is significant for those working in other fields and addressing other problems. Its experience is encapsulated in the new meanings that, thanks to its activities, have been attributed to the adjective "slow" and that we can refer to as the "slow approach".

Above all, the slow approach means the simple, but in current times revolutionary, affirmation that it is not possible to produce and appreciate quality if we do not allow ourselves the time to do so, in other words, if we do not activate some kind of slowdown. However, slow does not only mean this. It also means a concrete way of actually putting this idea into practice. It means cultivating quality: linking products and their producers to their places of production and to their end-users who, by taking part in the production chain in different ways, become themselves coproducers.

So, the slow approach outlines a new production and consumption model that is at the same time both subversive and feasible. While clashing head on with the ideas and practices of today's prevailing globalisation, it can be enacted locally both immediately and, as Slow Food has proved, successfully.

In our opinion, the great potential of the Slow Food experience needed to be better understood, both in terms of its nature as a strategic project for the development of new food networks and, as is of greater interest to us here, in its more general potential as a contribution to the definition of new ideas on quality, well-being and development models.

\subsection{Design as a continuous change}

Design is changing. The issues it addresses are changing. Its tools are changing. Whether aware of it or not, the people who design are changing. There is nothing strange or new in this: in a society in transformation, design, by its very nature, cannot but change.

At the same time, the way this change in design is taking place is contradictory: on one hand it is becoming more and more spectacular in its actions and in the media role of its actors, with design becoming an integral part of the communication system and (some) designers taking part in the star system. We are by now familiar with this spectacular evolution in design, but as we said,something else is also happening, something that is very interesting. Briefly, we can observe that a "new design" is emerging: a design that adopts a systemic view, that 
looks at the complexities of social networks, develops a capacity for listening and interrelates with the creativity and diffuse entrepreneurship that characterise contemporary society. In so doing it becomes an active part of the transformation processes underway and in those that must take place, confronted as we are with the enormous issues at stake.

This second line of evolution is, in our opinion, what lends design a potentially strategic role in the definition of new ideas of well-being and of ways to achieve it. At the same time, it proposes a new idea of a design potential that is as yet scarcely understood. This is not only because it materialises in complex activities that are not exactly easy to photograph, but also because it breaks so deeply with tradition that many of those who successfully "design" in this emerging mode are neither designers nor see themselves as such. Vice versa, many who are indeed designers, do not recognise these activities as being a true design mode.

Consequently, we need to facilitate a debate that makes the nature and potentiality of this "new design" clearer. This means discussing whether and how design can contribute in the field of systems and steer the transformations underway towards sustainable ways of living and producing.

\subsection{Why Slow+Design}

For numerous reasons we thought, since the end of the 90's, that it was opportune to bring these two themes of slow approach and new design together for the mutual support they can offer each other: the slow approach can open up new opportunities for design while this new design can bring useful conceptual and operational tools to the slow approach.

Before expanding on this statement some preliminary remarks are due. The encounter between design and Slow Food has already taken place. In particular, thanks also to Slow Food, the design community has long recognised the cultural value of food and has become particularly dynamic in this direction and towards associated places, services and products. However, in our opinion, there are worrying aspects in the way the phenomenon has been presented so far.

The risk we see is that design interest in food field may be limited to its spectacularisation, i.e. to the superficial designing of food experiences as an end in themselves, and to the spectacular consumption of what remains of a precious historical heritage of skills and expertise, flavours, places and social customs. In other words, the risk is that the meeting of design with food may develop in the opposite direction to what the Slow Food experience, if correctly interpreted, is proposing. In so doing we also risk losing the possibility of using the fundamental lessons that Slow food has taught us in other fields of instruction i.e. what we have called the slow approach.

So, the convergence of slow approach and design merits further study. This means that Slow Food must be seen as an extraordinary example of "de facto design" from which the designer (i.e. the "explicit design") community has much to learn and vice versa, that new design must propose and bring to light skills and abilities able to foster the consolidation and extension of the slow approach.

\section{Project experiences}

2.1 The match between Primary Design and Ecodesign 
The Sustainable Sensoriality expression wants to combine both worlds of sensoriality and sustainability, conceptual and operational dimensions of design, perhaps too long disjointed and not communicating, but that I have had the occasion to deeply practice into the casualty of my career as an architect and designer. I will not make it here, however, the subject of a theoretical or conceptual discourse, but I want to give a simple tale of what happened through experiences.

On one hand my experiences in the world of sensory quality and the design of the subjective variables, started with the students of Clino Trini Castelli and Antonio Petrillo, at Domus Academy Master programme in the mid80 s in the Primary Design classrom. In the coordination of the Domus Academy Research Centre, I was able to experience the design and enhancement of sensory qualities to new materials (Abet Laminati and Lorica projects), the definition of quality perception of artificial environments like auto (Bertrand Faure Automobile project) rather than control rooms in power plants (Mitsubishi Heavy Industries). In addition, through pilot projects, such NEOLITE for Assoplast about the identity and performance of recycled plastics from collection of municipal solid waste, they were anticipated and insights in a nutshell some of the arguments on traceability that we will better undestood later on.

On the other hand there are my experiences between principles and pragmatic formulations on EcoDesign and Design for Sustainability, through many authors, texts and testimonies that helped us to understand the complex, cyclical and systemic value of our environment. In 1994, the environmental issue exploded in Italy, and I was appointed to set the Design section of the first exhibition on aspects of environmental sustainability at the Mole Antonelliana in Turin.

Consequently I participated to many initiatives, from 18th Milan Triennale (il giardino delle cose) as well thanks to the National Institute of Bio-architecture: I have often been involved in research projects and exploration around the concept of sustainability, as it happened for example also in Solid Side project with the idea of minimum goods. However these worlds and research proceeded in a parallel way: the first dimension is exploring the sensory qualities and criteria of phenomenological enjoyment of our artificial landscape, while in the second were defined criteria and attention to ensure ethically and pragmatically, a better world, able to withstand the increasing complexity of production logic and consumption.

At the center of the process it was always placed the individual and the quality of its artificial environment, but in the first case the focus was on experiential and individual processes, while in the second those productive and social.

I should thank my next experience from 1997 to 2000 within Philips Design and mainly the attitude of Stefano Marzano's visioning project team, if I began to glimpse the close connection between the two faces of the same coin, to combine aspects of perception and cultural links with the technical dimension and management, sensory and politics, phenomenology and business.

\subsection{Exploration of the SLOW model extensions at the Design Faculty of Milan Politecnico}

Returning now to the empirical definition of the concept of Sustainable Sensoriality, it is certainly not by the sum of two terms, rather by the theoretical merge of two disciplinary worlds, or just listing the heterogeneity of my professional experiences, that we create a new design dimension. 
So the story starts to produce a summary, after my meeting with Giacomo Mojoli, when he was vice president of Slow Food.

In 2001, following the provocative reflections useful for the japanese exhibition Design as Lifestyle in Kobe and Yokohama, where I invited Slow Food to represent the category of Leisure time into the exhibition (direction by Andra Branzi, setting design by Toyo Ito), we decided to explore some more about of the issues raised together, in a new and unprecedented joint educational activities: we orchestrated a project laboratory at the Faculty of Design of Politecnico di Milano (Academic year 2001/2002 ) called SlowLife, together with Aristide Barone, designer manager of Mares.

We identified as design theme the "slow qualities": the sensory and cognitive understanding of the processes experienced by the consumer, in tourism and into the virtual world that anticipates the experience, defining a format of travel agencies intended as "portals of slowness". I still remember this workshop as one of the happiest and more surprising among those I carried in more than 20 years of teaching experience at the Politecnico di Milano: several of my following design partners, such as Stefano Mandato, emerged from this unique opportunity, between refined tastings of Barolo Chinato and chocolate, charismatic lessons from the free diving world champio.

Later on, in 2003/2004, with Giacomo we repeated the experience during the Bormio 2005 Ski World Cup and Torino 2006 Olympics, working with students on how a global formats, such as World Cup or the Olympics precisely, could in fact serve to discover, evaluate and communicate local dimensions of product and specific sensory experiences. Also on this occasion, besides the tasting of the Valtellina Sfurzat or understanding of tactile quality in a Zegna cashmere, it has revealed how much local identity, submerged and not valued, it can explode and become tangible if you manage to make it traceable, traslating processes into forms not necessarily complex and airtight.

\subsection{Extending the Slow approach from Politecnico to other institutions and partners}

As a corollary on our educational experiments, with Giacomo Mojoli we published some articles that appeared in Lineagrafica magazine: Slow Communication and Slow cities. The aim was to identify and describe, with cases and concrete examples, the obvious transmigration of typical values from the Slow Food philosophy into other sectors.

I remember that the same issue about the valorization of local identities, it was part of a series of interesting projects along with Ampelio Bucci brought forward in the second mid-90s in the Master in Design Direction of Domus Academy, making students work, after a year of full internationalization in the Milano design world, on their own places of origin and on their cultural roots, inviting them to find a business idea that exploit local resources: landscape, crafts, gourmet products, materials, plant or animal species....wete intended as design objects.

This issue was also addressed in a seminar (organized by myself and Giacomo Mojoli) at Domus Academy in 2004 into the first Master in Business Design, with the participation of companies such as Zegna, Mares, Barilla, and then further developed into an interesting thesis presented at the Politecnico di Milano, entitled Slow Design from the preservation of material culture to design paradigm, conducted by Guido Parlato, who was a student in 
our first workshop. It looked like we were to closing a loop. So the final consequence of all these action its was the international seminar we organized putting together the main design schools in Milan (Politecnico di Milano, Domus Academy, Istituto Europeo di Design) in 2006: we wanted to help to clarify both the nature of the slow approach and the potential of the new design mode, putting them to the test by confronting problematical issues and real, significant cases.

The seminar was organised in sections where the general theme was introduced and developed along 3 lines of reflection, with the presentation of typical concrete cases:

- The valorisation of local resources and the distributed economy, relevant to local development and its new economy facilitators;

- Transparency in production systems and de-intermediation, relevant to the extended development of new producer and co-producer networks

- Product experience and sustainable sensoriality, relevant to quality and its social and environmental sustainability

Among the subscriber of the SLOW + DESIGN manifesto, A slow approach to distributed economy and sustainable sensoriality, we do include: Alberto Capatti, Giulio Ceppi, Aldo Colonetti, Ezio Manzini, Anna Meroni and Giacomo Mojoli.

Sustainable sensoriality has reachen its thoeretical peak.

\section{Case histories}

Designing new relationship to envision innovation through sustainable sensoriality.

Sustainable sensoriality means today to develop and built new scenarios and to generate new behavioural attitudes, as this is not trustable or builtable just pushing technologies or generating new business strategies.

The sociocultural issue is the real and unique link to innovation and the acceptance and deep understanding of overall processes are the only tools and leverages that could guarantee satisfaction and feasibility.

According to this vision, where social actors and stakeholders are the key to success, design is a fundamental ingredient to the innovation process itself, it is the fuel for the eco-business where people have to trust and share, to modify their habits and produce a new attitude and culture.

Envisioning new services, new behaviours through communication and new spaces and architectures, finding the right aesthetics and interface to talk to people: this is what ecodesign is today, not the application of technical and engineeristical rules form some green manual or eco-dictionary.

Here you have some case histories and concrete practice, starting from the 90's (let's say in parallel with Slow Food, without consciuosness maybe...) 
To build an office addiction to an incinerator plant, effected by the so called NIMBY sindrome (Not In My BackYard), as in the SILEA case, does not mean to built just a Zeroimpact architecture (one of the first realized in Italy), but to generate a relational platform, to convey and produce people energies into new channels, to relate the external world with the inner problems of the company.

The eco-park, generated using hot water coming from the chimney, means a place of educational value and a relational platform open to the local citizens, an accessible and free place to interact with the local community as well as with specific actors (biologists, gardeners...) to transform energy into life, and viceversa.

\subsection{Arinaga wind park in Canary islands, $1999(\mathrm{E})$}

To understand the visual impact of something thought as absolutely clean and sustainable, as it happens for an eolic park, it means for UNELCO (the local energy provider) in Canary Islands to give a different potential to their business. Analysing the different strategies and opportunities in term of color matching and balance of the visual pollution of these big environmental structures, we did create a new path to make the local communities feel as they were the real owners of the technology, not viceversa, as it happens too often.

After 2001, together with Giacomo Mojoli we developed several projects in a 4 hands modality, always based on sustainable sensoriality approach, such as:

3.3 Womb glass for Averna (2006)

The design of an amaro liquoer tasting glass was coincived on an experience based research aimed at enhancing amaro liquoeur Mediterranean qualities and let the customer get closer to the product by mean of a multi-sensorial ritual.

Presentation and communication event at Milano Triennale used a strong iconographic apparatus, including rosemary -scented cards sas memorabilia for guided tasting.

When Campari company bought the sicilian brand from Averna family in 2015, a strong advertising campaign featuring the american actor Andy Garcia and based on Womb ritual has been activated and promoted on different media, from television to Facebook. (Figure 1)

\subsection{Ottagono dei valori identitari del nuovo artigianato for Confartigianato (2008)}

The project developed with Confartigianato is aimed at interpretating the new role of craftmanship according to the global market and the new developing scenario between craft production and industrial competition.

Eight polarities have been outlined: each one is based on a couple of values helping craftsmen to find their emerging role, understanding their specific skills and communication qualities.

Workshops and fairs (Milan and Rome) have been the places selected to present and test the strategic tool: a special session has been organized with Fondazione Giannino Bassetti in 2013 in San Francisco, facing the 
american makers culture.

\subsection{Cuvee design kit for Contadi Castaldi (2009)}

Cuveè design kit is linked to the process of making a special Contadi Castaldi cuveè and to the all variables in it, such as know how, identitary values and sustainable sensoriality criteria.

The kit is meant for a use during wine tasting (instead of the former Gioco delle cuvèè, too expensive indeed), not only as a tool for a deeper acknowledgement, studied for connoisseurs as well as amateurs, explains the overall process and at the same time communicates the product in its unique complexity.

The kit as been presented at PAC-Padiglione di arte contemporanea in Milan and then tested in many occasions:

In 2010 a Roseè garden has been design in the vegetable garden of the Villa Reale di Monza, translating the kit into a multisensorial natural setting, expliciting smells, colours, textures...normally embedded into a cuveè.

\subsection{Autogrill Villoresi est, Lainate (2013)}

In terms of the effect of this energy, Villoresi East was conceived as a living organism sensitive to natural cycles and fed through the innovative combination of solar and geothermal energy,combining the energy of the earth and the sun. A sustainability project to 360 degrees has developed following the principles of the LEED Protocol (Leadership in Energy and Environmental Design) with design choices and plant aimed at reducing the energy and environmental impacts and to ensure integration with the territory and the surrounding landscape.

Technological and environmental impact:

- Geothermal plant to "thermal stack" with 420 probes lowered into the ground covering $85 \%$ of the needs during summer time.

- Captating roof with a surface of 350 square meters that capture, seasonally, hot or cold;

- Free cooling system that takes full advantage of natural ventilation for cooling;

- LED lighting for both the exterior and the interior area;

- System of rainwater and ground water collection for air conditioning, irrigation, toilet and fire reserve;

- $19.000 \mathrm{mq}$ green area (about $30 \%$ of the total area), with the planting of one tree per six parking spaces, in continuity with the landscape vegetation.

The building is spread over an area of about 2,500 square meters with a skeleton made entirely of laminated wood PEFC certified from forests managed in a sustainable manner. Is also characterized by the use of environmentally friendly construction materials and $100 \%$ recyclable. 
Overall accessibility of services is one of the most significant features of Villoresi, where the design of the layout, furnishings and equipment, is based on the principles of Design for all and DASA Certification Register with the aim of obtaining the homonyms quality marks for accessibility.

In terms of interior design Villoresi East is a pioneering experience of architectural barriers and restrictions to the free movement of customers, which elevates the service area to best practices for accessibility for all. The interior design has been elaborated from the multiplicity of needs of people traveling (businessmen, families, women truckers, children, elderly, disabled, blind, etc.... ). (Figure 2)

\subsection{Sciur wine for Nino Negri, Valtellina, 2014}

The original and bold choice to set up the project of a fully sustainable wine required interaction and verification with young people of different countries and cultures from a path of studies based on a systemic approach, similar to that of the Master in Strategic Design form Politecnico di Milano.

This is because Sciur, nevertheless of its 15.000 bottles a year, is not a mere product. It is not just the end result of a varied production line but it involves a set of planning sequences and activities intended to be a potentially repeatable virtuous example.

We hope that this wine can be considered an operational tool, a dynamic means of transformation, and that it may become a pragmatic example of how in the "world of wine" (and not only) the rules of the game are changing in terms of demand and supply, and how only discussion, meetings, trips, experimentation and respect for tradition may provide valid feedback for the future.

The word "Sciur" cannot be found in an Italian dictionary but only in a dictionary of the Lombardy dialect. In Valtellina, as a sign of respect, it was the name given to Carlo Negri, who founded the winery of the same name in 1897. Apart from this interesting fact, any reference to dialect is incidental, since Sciur is used as an acronym for serendipity thanks to research by the students of the Polytechnic University of Milan who found 5 key words that characterise the project and the wine to be produced.

They are explicit thanks to their meaning, and attractive and virtuous due to their practical and cultural implications: Sustainable, Concrete/practical, Innovative, Unique, Responsible.

The project includes Internship projects for young builders in collaboration with the Polo di Formazione Professionale Valtellina for learning the techniques of maintenance and construction of dry stone walls and 1 euro for each bottle of Sciur sold it is donated to projects concerning the protection and preservation of dry stone walls, a very important heritage for Valtellina. (Figure 3)

I hope that all these examples are clear and succesfull enough to show you as we do not get anything sustainable (and profitable) if not because through design we try to show people a different world where new qualities are clearly emerging and where realtionships among different actors are more fluid, transparent and friendly.

This is the meaning for design, today and hopefully, tomorrow. 
Bibliography

Agamben, G. (2004). Genius. Nottetempo.

Ceppi, G. (2011). Design storytelling. Milano: Fausto Lupetti editore.

Ceppi, G. \& Zini, M. (1996). Bambini, spazi, relazioni. Edizioni Reggio Children.

Leroi-Gourhan, A. (1965). Le geste et la parole. Editions Albin Michel.

Manzini, E. (1990). Artefatti. Milano: Edizioni Domus Academy.

Moles, A. \& Rohmer, E. (1982). Labyrinthes du vecù. L'espace: matiere d'actions. Paris: Librairie de Meridiens.

Petrini, C. (2005). Buono, Giusto, Pulito. Milano: Il saggiatore.

Pine, J. \& Gilmore, J. (1999). The experience economy. Boston: Harvard Business School press.

Trini Castelli, C. \& Petrillo, A. (1986). Il lingotto primario. Milano: Arcadia edizioni.

Abstract: Starting from the Slow Food experience and its international success, the author, together with Giacomo Mojoli (former vicepresident of Slow Food) starts to question about the trasfer of the slow approach into design practice.

This means discussing whether and how design can contribute in the field of systems and steer the transformations underway towards sustainable ways of living and producing. The Sustainable Sensoriality expression wants to combine both worlds of sensoriality and sustainability, conceptual and operational dimensions of design, but deeply practiced into the authors's activities as architect and designer and explicited in many teaching practices and design case histories.

Key words: Sustainability - Sensoriality - Slow approach - Innovation - System design - Changment by doing.

Resumo: A partir da experiência do Slow Food e seu sucesso internacional, o autor, juntamente com Giacomo Mojoli (ex-vice-presidente do Slow Food) começa a questionar a abordagem slow na prática do design. Isto significa que discutir se o design pode e como pode contribuir para a área de sistemas e direcionar as transformações em curso produzindo modos de vida sustentáveis. O termo Sensorialidade Sustentável quer combinar os mundos da sensualidade e da sustentabilidade, dimensões conceptuais e operacionais do design, mas profundamente praticada nas atividades dos autores como arquiteto e designer, e explicitada em muitas práticas de ensino e em muitos casos estúdio de design.

Palavras chave: Sustentabilidade - sensorialidade - abordagem slow - inovação - sistemas de design mudanças na prática. 
Slow+Design as sustainable sensoriality: an innovative approch aimed to explore the new relationships among design, innovation and sustainability fue publicado de la página 135 a página146 en Cuadernos del Centro de Estudios de Diseño y Comunicación №70 